equipment and other gear which he used; his lecture was illustrated by most beautiful slides.

As usual, a main feature of the meeting was provided by the exhibitions of apparatus and books by manufacturers and publishers; these, together with the exhibition of teaching apparatus devised by members, were bigger than ever before, and strained the accommodation of the Royal College of Science to the utmost. The Home Office contributed a display of apparatus used in Givil Defence work by technical reconnaissance officers, and also lent a control set and 'walkie-talkies' so that officers of the Association could maintain contact with the secretary's office from any part of the College. Some sixteen firms were visited by members during the afternoons, as also were the High Pressure Laboratories of the Chemical Engineering Department at the Imperial College. In addition, on each afternoon scientific films were shown, some of which wero introduced by Dr. J. A. Harrison (Educational Foundation for Visual Aids).

The meeting created a record for attendance, and the Association must count itself as singularly fortunate in this year's president, Sir Edward Salisbury, who insisted on sharing in all the activities; his zest showed that he was not content with precept in his address, but followed it with action during the meeting.

\section{FARMING HISTORY IN GREAT BRITAIN}

$\mathrm{F}$ ARMERS, industrialists and scholars from all over Great Britain attended a joint meeting of the British Agricultural History Society and the Association of Agriculture, which was held in the University of London on December 3. Sir James Scott Watson, president of the History Society, took the chair, and three papers were read, one in the morning and two in the afternoon. This event, which is one of the two annual meetings convened by the Agricultural History Society, is usually open to nonmembers on payment of the conference fee.

The morning paper, read by Dr. H. Harnshaw Thomas, prosident of the History of Science Society, dealt with the life and writings of Richard Bradley, F.R.S., who lived in the early years of the eighteenth century. The paper gave much food for thought, for Bradley came very close to some of the most modern scientific discoveries. By a series of experiments he found that variegated leaf colours could be induced in healthy plants by grafting scions of discoloured plants. The variegation, which is really a virus disease, was, he found, transmitted through tho circulation of the sap. Similarly, he was able to produce the breaking of tulip bulbs, which was forgotten or neglected until Sir Daniel Hall, all unknowingly, so it is thought, repeated Bradley's experimental work on modern lines. Besides his achievements in pure science, Bradley was a severely practical man. 'Through correspondents and personal observation he collected and recorded a great mass of information about the farm practice of his day. As Dr. Hamshaw Thomas said, a complete description of English farming methods of the early eighteenth century can be compiled from his work. Until the present day, Bradley has been regarded as somewhat of a charlatan, but Dr. Hamshaw Thomas's work has done much to retrieve his reputation.
After lunch the first paper was by Prof. Cyril Tyler, of the University of Reading, who dealt with the historical development of feeding standards for livestock, a subject that must be very close to the hearts of farmers in these times. Prof. Tyler ranged over the ages from classical times until the present day, describing the theories of the ancients and the slow progress that was made in gaining real knowledge of the subject until von Thaer's work in the early nineteenth century. It was unfortunate that von Thaer chose such a variable as good hay for his basic unit, but his work pointed the way. Many German and British chemists followed in his steps and, with slowly increasing knowledge, have to-day been able to lay down simple and practical rules for tho breeder, dairy farmer and meat producer alike. It is a fascinating story and demonstrates, if that is necessary, that the findings of science are of universal application.

The third paper was rather more recondite and dealt with pollen analysis and its bearing on agricultural history, being given by Mr. J. W. Franks, of the Department of Botany, University College, Leicester. Mr. Franks demonstrated how what happened in districts now covered with peat or fen can be discovered by cutting down through the layers. The depth of the layers and other indications show how long they have taken to accumulate. In these layers of peat the pollen of the various flora that flourished is embedded and preserved, and by carefully collecting this pollen, identifying it and counting it, the flora of that particular age can be deduced. If man was living in the place when the pollen was deposited, his activities in growing cereal or other crops, or the effect of grazing animals, will be shown by the different pollens recovered.

All three papers dealt with subjects that were well worth while, and the conference was a great success. Those interested in this field should write to the Honorary Secretary, British Agricultural History Socjety, Mr. J. W. Y. Higgs, at the Museum of English Rural Life, 7 Shinfield Road, Reading.

\section{GOVERNMENT RESPONSIBILITY IN INDUSTRIAL RESEARCH}

$T$

HE extent and character of the rosponsibility taken by governments for research varies enormously. In the scientifically more advanced countries, the government attitude ranges from the benevolence combined with restricted actual participation to be found in Germany and the United States to the complete control of science exercised in the U.S.S.R. Even within the British Commonwealth, where there is a common tradition of government, the countries have developed different ways of reaching the level of research activity essential in a rnodern State. Some of the differences and the reasons for them were brought out in a discussion on "Government Responsibility in Industrial Research" held at the Society for Visiting Scientists on December 6 under the chairmanship of Sir Henry Tizard. The principal speakers were Dr. E. W. R. Steacie, president of the National Research Council of Canada, and Dr. B. K. Blount, deputy secretary of the Department of Scientific and Industrial Research, and there were contributions from a number of Commonwealth countries and the United States. 
Dr. Steacie said that the structure of research in Canada differs markedly from that in Britain or the United States. As a pioneer country, the primary industries developed first, and long before there was a National Research Council research organizations were set up in government departments to deal with their problems. In the initial stages the Canadian secondary industries were mostly branches or subsidiaries of firms in the United States or in Britain, and any research was done by the parent company. This has resulted in a very minor amount of research being done by industry, and a correspondingly greater proportion having to be done by the government for industry.

The National Research Council, charged mainly though not exclusively with the responsibility for industrial research, was set up in 1916 by the Canadian Government at the suggestion of the British Government. At that time there was little secondary industry in Canada, and most of the plants established to meet the needs of the First World War disappeared at its end. It was not until the Second World War that major development of secondary industry took place. In some ways development in Canada has paralleled that in the United States, but "one war behind". In the latter, industrial expansion took place in a period when research by industry was developing in the world generally, but Canadian expansion is happening at a time when there is already a great deal of research abroad. Canada has never gone through a period when there was a large body of research in industry. While there is now a tendency even for subsidiary companies to set up research organizations, the major responsibility for keeping Canada abreast of the times through research falls on government organizations.

It is always difficult to get accurate figures for research expenditures; but the amount allocated in 1954 by the Canadian Government for research in the primary and secondary industries and health was about 43,000,000 dollars, excluding military and atomic energy research ; this does not include expenditures by either Provincial authorities or universities. No exactly comparable figures are available; but roughly the Canadian Government is spending twice as much per capita on eivil research as the United States Government. On the industrial side, however, the contribution is extremely small. The figures are very unreliable; but they do support the thesis that what is wanted in Canada is a large increase in research in industry rather than by government.

Dr. Steacie went on to describe the organization of research in Canada and the ways in which assistance is rendered to industry. The Department of Agriculture operates large research and demonstration establishments with an annual expenditure of about $17,000,000$ dollars. The mining industry is served by the Department of Mines and Technical Surveys, and the ore-dressing laboratory of this Department is particularly noteworthy because the free service which it gives in investigating suitable methods of treatment for the ores from new mines has done so much to aid the development of Canadian resources. The National Research Council, on its own initiative, undertakes long-term research for secondary industry and undertakes shorter-term research under contract for individual firms or groups. The proportion of the expense borne by the industry varies with the circumstances. The research councils of the Provinces work mainly on the shorter-term problems of local industry, sometimes on contract, and in some respects fill the place taken by the large specialized consulting firms and sponsored research in the United States. Research associations, so successful in Britain, are practically non-existent in Canada, partly because of the high proportion of subsidiary firms and partly because of the scattered distribution of industry. Only the pulp and paper industry operates its own co-operative laboratories.

Canada, like every other country, is faced with the problem of getting technical information into the hands of industry. The needs of primary industry are looked after by the appropriate government departments. For secondary industry, lacking research associations as a channel for disseminating information, the Research Council has set up a Technical Information Service which works closely with the Provincial research councils and other bodies in active measures to bring the benefits of new and existing technical information to industry.

Dr. Blount contrasted the Canadian and British conditions, pointing out that Canada is a country with large resources and capable of feeding itself, and that industry in Britain is long established compared with Canada, with a high proportion of craft industry where the best techniques have been found by trial and error over a long period. Even in such industries, however, the need for research is growing because of changing conditions, particularly with regard to raw materials and the need for increased scientific control with the gradual disappearance of the traditional craftsman. The small size of most of the firms gives the opportunity for real help through research associations.

While the figures are not very reliable, the total expenditure on research of all kinds in Britain is probably about $£ 300,000,000$, or about one-fifth of the corresponding figure for the United States. It is almost impossible to estimate the government expenditure on research applicable in civil industry, since much of this is included in the budgets of the Armed Services. It is fairly certain, however, that the expenditure by industry is at least equal to that by government, in contrast to the Canadian situation.

After Dr. Blount's talk there were many contributions to the discussion, including a notable one by the chairman himself; but in general three topics were considered : research in India, the difficulty of assessing research effort, and research associations. In India, as in Canada, attention was first given in the past to the primary industries, namely, agriculture and forestry. Now, industrial research is increasing in importance, the expenditure having risen from $£ 50,000$ in 1940 to about $£ 900,000$. Government research will probably always be dominant in India because of the creation of State industries.

The need for more reliable figures on research expenditures was stressed, particularly as a guide for the distribution of effort in view of the great cost of development and full-scale exploitation as compared with research. Several speakers referred to the value of studying the man-power rather than expenditure, especially in attempting to compare the situations in different countries.

Research associations have been successful in New Zealand where there is a preponderance of small industries; but in Australia they are few in number and indifferently successful. In the United States the place of research associations is taken by the large institutions undertaking sponsored research. Several speakers told of the interest of large firms, and were 
of the opinion that the smaller firms which the research associations are particularly designed to help are often "poor mombers". There was general agreement that the best place to do industrial research is in industry and that, ideally, government and co-operative efforts should cover those fields not adapted to research by individual firms.

\section{AFRICAN HONEY-GUIDES}

$\mathrm{A}$

MONG the strangest forms of animal behaviour $A$ is that of the honey-guides, African birds distantly related to the American woodpeckers, which 'guide' men, baboons and ratels (honeybadgers) to the nests of wild honeybees-supposedly so that these nests can be broken open.

A study of the behaviour is described by Dr. Herbert Friedmann, U.S. National Museum curator of birds, in a bulletin issued by the Smithsonian Institution, Washington. Dr. Friedmann has observed at least twenty-three instances of the habit and has collected other well-authenticated data from African associates.

Dr. Friedmann describes the behaviour as follows : "When the bird is ready to begin guiding, it either comes to a person and starts a repetitive series of churring notes or it stays where it begins calling these notes and waits for the human to approach it more closely. If the bird comes to the person to start leading him, it flies within 15 or 20 feet from him, calling constantly and fanning its tail. If it waits for the potential follower to approach it for the trip to begin, it usually perches on a fairly conspicuous branch, churring rapidly, fanning its tail, and slightly arching and ruffling its wings so that at times its yellow shoulder bands are visible.

"As the person comes to within 15 to 50 feet from it, the bird flios off with an initial conspicuous downward dip, and then goes off to another tree, not necessarily in sight of the follower ; it is more often out of sight than not. It waits there, churring loudly until the follower again nears it, when the action is repeated. This goes on until the vicinity of the bees' nest is reached. Here the bird suddenly ceases calling and perches quietly in a tree nearby. It waits there for the follower to open the hive and usually remains until the person has departed with a collection of honeycomb, when it comes down to the plundered bees' nest and begins to foed on the bits of comb left strewn about. The time during which the bird may wait quiotly may vary from a few minutes to well over an hour and a half."

African natives regard the bird as an almost infallible guide to honey. They try to attract it by grunting like a ratel or chopping on trees to imitate the sound of opening a nest. Dr. Friedmann suggests that the habit is purely on an instinctive level and is not a deliberately associative act. It presumably originated before the advent of human beings, perhaps starting with the ratel, that still co-operates with the bird, and whose place in the association the African natives have deliberately tried to take. The honey-guide does not seem interested in the honey per se, or in the grubs of bees found in the nests. It has an insatiable appetite for the beeswax, which it will take wherever it can be found. With various collaborators, Dr. Friedmann is now carrying out an intensive study of the mechanism of wax digestion.

\section{THE NATIONAL TRUST ANNUAL REPORT}

$\mathrm{T}$

HE sixtieth annual report of the National Trust, prosented to the annual general meeting in Manchester on November 24-the first to be held out of London-records that there are now a hundred and twenty historic houses in the care of the Trust, which owns more than 220,000 acres and has a membership of more than fifty thousand, compared with a membership of seven thousand in 1945 when the Trust had sixty-three houses and owned 107,000 acres, and in 1914 a membership of $725,5,500$ acres and a handful of historic houses. The National Trust Act of 1937 specifically extended the purposes of the Trust to include the preservation of furniture, pictures and other works of art, and since that date the Trust has become responsible for many important collections associated with the country houses under its care. Its responsibility for works of art is likely to increase since the Finance Act of 1953 empowered the Treasury to accept, in payment of death duties, chattels associated with historic houses in the ownership of the 'Trust. The annual roport gives some account of the work of the Trust in this field, and at the annual general meeting Prof. A. B. Blunt, surveyor of the Queen's pictures and director of the Courtauld Institute, who has for some years been the 'Trust's honorary adviser on paintings, also described some of the maintenance problems that arise.

The report emphasizes that the Trust does not regard its primary duty, in respoct of its farmlands and the preservation of the unspoilt landscape committed to its care, as in any way conflicting with the interests of good farming, and the policy of modernizing the farms continues steadily. Deeds of dedication have now been completed with the Forestry Commission in respect of some 4,699 acres of the 'Trust's 30,000 acres of woodland, including 1,095 acres at Clumber, where, with the release by the Army of 850 acres, the whole property is now open to the public. For the first time since 1947, the accounts show a small surplus (£979) on the maintenance and administration of the Trust's general properties; but, although the income from annual

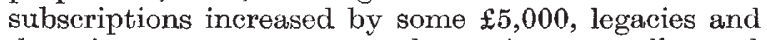
donations are at present decreasing annually, and a large increase in membership is essential if the Trust is to do no more than watch over a fraction of the property requiring its care.

The Trust aims at a membership of seventy thousand before the end of 1956, and, in stressing the urgent need for such an increase, Lord Chorley warned the annual general meeting of the great danger of complacency. The danger to the great country houses is more acute than ever, and at present the Trust can only accept such houses if an ondowment for all time is offered with the house. Lord Derby, who also addressed the meeting, stressed the voluntary standing of the Trust and made it clear that the Trust depends on private support and not on national contributions. He said that he was impressed by the small amount of litter left by the public when they visit Knowsley, in contrast with the amount left at many of the 'Trust's properties where admission is free. Reference was also made at the annual meeting to the launching of a scheme of corporate membership, by which it is hoped to enrol organizations such as industrial firms. 